\title{
POTENSI HERITAGE YANG DIMILIKI OLEH DESA WISATA TAMKESI KABUPATEN TIMOR TENGAH UTARA SEBAGAI DAYA TARIK WISATA
}

Arichtia Praevianti Taolin a, 1 , Saptono Nugroho a, 2

1arischtia_lin@yahoo.com,22snug1976@gmail.com

a Program Studi S1 Destinasi Pariwisata,Fakultas Pariwisata,Universitas Udayana, Jl. Dr. R. Goris, Denpasar, Bali 80232 Indonesia

\section{ABSTRACT}

This research analyzed the rural heritage tourism development strategy in Tamkesi, North Cental Timor Regency as a tourism destination. This research uses qualitative approaches. Data collected by observation, in-depth interviews, and literature study. This research used qualitative data analysis. The informant collection techniques used purposive sampling. Tamkesi Traditional Village has tangible heritage and untangibile heritage which can become a tourism main attraction. The results showed that tourism potentials of the village of Tamkesi such as natural tourism resources, accessibility and some tourism facilities and infrastructure are inadequate. Strategies that can assist in developing cultural tourism in rural area heritage in Tamkesi Village are: by knowing the type of cultural amenities in Tamkesi village, that were tangible and intangible heritage facilities. The tourism potentials of the village of Tamkesi among others natural tourism resources, cultural, heritage, accessibility and supporting facilities which have not been packed and managed well, and some tourism facilities and infrastructure are inadequate.

Keywords: Heritage; potential; rural tourism; Tamkesi.

\section{PENDAHULUAN}

Pariwisata pada dasarnya merupakan perjalanan yang dilakukan seseorang dalam waktu yang sementara dari suatu tempat ke tempat lain yang bertujuan untuk menikmati kegiatan pertamasyaan dan bukan dengan maksud untuk mencari nafkah di tempat yang dikunjunginya. Pariwisata pusaka (heritage tourism) merupakan segmen pariwisata yang semakin populer dan semakin banyak diminati karena wisatawan menginginkan pengalaman nyata dengan budaya yang mengandung unsur edukasi.

Pariwisata pusaka telah berkembang dengan pesat terutama di negara maju, sehingga mampu berkontribusi terhadap pelestarian situs-situs pusaka dan dapat memberi manfaat bagi warga lokal. Desa Wisata Tamkesi merupakan salah satu destinasi di Pulau Timor yang merupakan kampung tradisional yang menyimpan nilai-nilai sejarah dan budaya yang kental. Jumlah kunjungan wisatawan pada tahun 2013 ke Desa Wisata Tamkesi berjumlah sekitar 500 orang dan jumlah kunjungan tersebut naik pada tahun 2014 hingga mencapai 625 orang wisatawan.

Wisatawan yang berkunjung ke Desa Tamkesi didominasi oleh wisatawan asing yang berasal dari negara Inggris, Australia, Belanda, Jepang, dan Perancis.
Tabel 1. Tabel Jumlah Kunjungan Wisatawan ke Desa Wisata Tamkesi

\begin{tabular}{ccc}
\hline No. & Tahun & Jumlah wisatawan \\
\hline 1. & 2013 & 500 orang \\
2. & 2014 & 625 orang
\end{tabular}

Sumber : Hasil Penelitian (2015)

Desa Wisata Tamkesi sejak 1865 tahun lalu merupakan pusat Istana Kekaisaran Kerajaan Biboki yang dianggap sebagai sebuah perkampungan megalitik yang dan keramat.

Melihat fenomena-fenomena tersebut, maka penelitian ini penting dilakukan untuk menentukan potensi heritage yang mendukung pariwisata di Desa Wisata Tamkesi. Sehingga potensi-potensi heritage di Desa Tamkesi dapat dikembangkan secara berkelanjutan dan memberikan manfaat yang signifikan terhadap kegiatan ekonomi masyarakat di Desa Tamkesi.

Tujuan penelitian dalam penelitian ini berdasarkan latar belakang sebelumnya, adalah: untuk mengetahui potensi heritage yang dimiliki oleh Desa Wisata Tamkesi Provinsi Nusa Tenggara Timur sebagai daya tarik wisata.

\section{METODOLOGI PENELITIAN}

Penelitian ini berlokasi di Desa Wisata Tamkesi, Provinsi Nusa Tenggara Timur. Penentuan lokasi dikarenakan desa wisata ini memiliki potensi heritage yang bisa dijadikan suatu daya tarik wisata yang dapat meningkatkan 
kepuasan wisatawan serta bertambahnya jumlah kunjungan wisatawan.

Jenis data untuk mengidentifikasi penelitian ini yaitu data kualitatif, serta sumber data yang dipergunakan dalam penelitian ini, yaitu: data primer dan sekunder, seperti: daftar potensi pariwisata di Desa Wisata Tamkesi, profil daerah penelitian dari Kepala Adat Desa Tamkesi, dan teori-teori dari berbagai pustaka yang digunakan sebagai landasan. Informan yang digunakan adalah informan pangkal yaitu Kepala Desa Adat Tamkesi; informan kunci, yaitu Kepala Bidang Kepariwisataan Dinas Pariwisata Kecamatan Kefamenanu Timor Tengah Utara. Analisis data yang digunakan dalam penelitian ini adalah menggunakan langkah-langkah pengumpulan data, mereduksi data, penampilan data, verifikasi dan penegasan kesimpulan.

Konsep yang digunakan dalam penelitian ini adalah Potensi Wisata, Komponen Utama Daya Tarik Wisata atau 4A, Desa Wisata, dan Konsep Heritage. Dalam penelitian ini, potensi wisata merupakan segala hal (potensi alam, budaya, dan potensi manusia) yang berguna untuk mengembangkan industri pariwisata di daya tarik wisata (Sukardi, 1998). Cooper (1993) menyatakan daerah tujuan wisata harus didukung empat komponen utama atau yang dikenal dengan "4A", yaitu: attraction (atraksi), amenities (fasilitas), accessibility (aksesibilitas), dan ancilliary (pelaku pariwisata). Desa Wisata menurut Chafid Fandeli (2002), yaitu suatu wilayah pedesaan yang menawarkan keseluruhan suasana yang mencerminkan keaslian desa. Hall dan McArther (1996) mengatakan bahwa heritage merupakan peninggalan warisan budaya yang ada dan dilestarikan hingga saat ini, yang berupa peninggalan tangible dan peninggalan intangible.

\section{HASIL DAN PEMBAHASAN \\ Gambar 1. Perkampungan Adat Tamkesi Biboki}

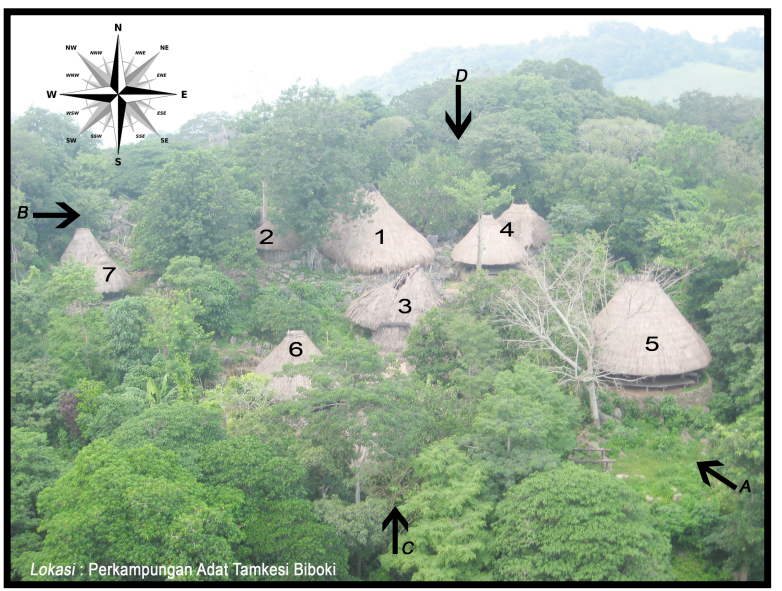

Sumber : Desa Adat Tamkesi (2015)

Desa Tamkesi adalah suatu kawasan pariwisata yang baru berkembang dengan potensi heritage dan dikelola oleh raja dan warga desa setempat. Desa Tamkesi masuk ke dalam wilayah Desa Tautpah dan berjarak $60 \mathrm{~km}$ dari Kecamatan Kefamenanu, Provinsi Nusa Tenggara Timur.

\subsection{Potensi Tangible Heritage dan Intangible Heritage Desa Wisata Tamkesi}

Suatu tempat dapat disebut sebagai daya tarik wisata jika memiliki ciri khas atau potensi yang membedakannya dengan daya tarik wisata lain. Potensi tersebut yang menjadi kekuatan sehingga dapat bersaing dengan destinasi wisata lainnya. Berikut potensi heritage yang mendukung dan merupakan langkah awal pengembangan Desa Wisata Tamkesi:

\section{Gambar 3. Potensi heritage Desa Tamkesi}

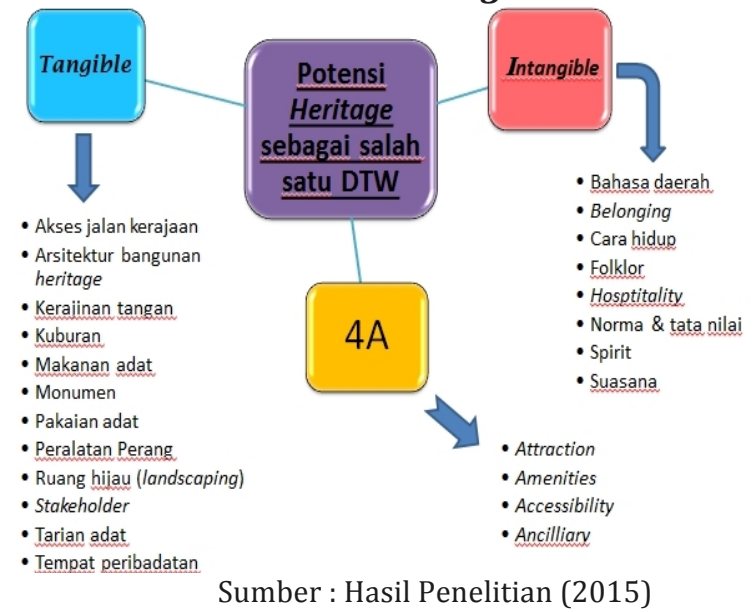


Tangible

1. Akses jalan kerajaan: Eno Paisanaunu, Eno Belsikone, Eno To Feto Ha'O, Eno Fanai-Naijuf.

2. Arsitektur bangunan heritage: Sonaf Neno Biboki, Paon Leu Neno Biboki In Maten'na, Lopo Tainlasi yang belum dan telah dipugar, Lopo Ha'O, Soan Unu, Sonaf Uskenat.

3. Kerajinan tangan: tenun, kuabe, feko, serta anyaman dan lontar.

4. Kuburan: Soanmisokan.

5. Makanan adat: mak pena, pen pasu, ut, sistunu, se'i bijae dan se'i fafi.

6. Monumen: Bahaen Nayufa, Batu berbentuk jantung, Tetu usi neno, Tugu perpisahan Kaisar Biboki dengan Liurai Sonbay.

7. Pakaian adat: motis, pilu, tais, tutus.

8. Peralatan Perang: Besi Tnais.

9. Ruang hijau (landscaping): Hutan, gunung, dan kebun.

10.Stakeholder: kelompok usaha pariwisata berbasis adat.

11.Tarian adat: Tari perang (tabso), tari likurai, tari bonet, tari gong.

12.Tempat peribadatan: Tetu usi neno dan Lopo Ha'O.

\section{Intangible}

1. Bahasa daerah: Bahasa Dawan Kromo.

2. Belonging royong (meup).

3. Cara hidup: melaksanakan kepada raja, taat pada titah raja dan mengikuti norma adat yang berlaku, tinggal di rumah tradisional Timor.

4. Folklor: Lokasi Tamkesi dipercaya menjadi pusat bumi sehingga dijadikan pusat kerajaan Biboki, Bukit Oepuah dan Bukit Tapenpah, upacara Tetu Usi Neno, Soanmisokan, dan Faotbeanmetan.

5. Hospitality (keramahtamahan): Penduduk desa sangat sopan, baik dan ramah, rumah penduduk cukup bersih dan nyaman, serta penduduk menjamu dan melayani wisatawan dengan baik.

6. Norma dan tata nilai: Tiga hal unik yang melekat pada diri Kaisar Biboki, pelanggaran hukum adat, larangan menjatuhkan barang dan berbicara kasar di sekitar sonaf.

7. Spirit: ainu uis neno (Tuhan dalam tradisi lokal) dan leluhur.

8. Suasana: Asri, tenang, aman, nyaman.

Menurut hasil penelitian yang diperoleh di Desa Tamkesi, potensi tangible heritage dan intangible heritage, yaitu: potensi warisan budaya tangible yang terdapat di Tamkesi berupa akses jalan kerajaan (eno: paisanaunu, belsikone, to feto ha'o, fanai-naijuf), arsitektur bangunan heritage (sonaf atau istana Biboki, paon leu neno Biboki, lopo, dan soan unu), kerajinan tangan (tenunan, feko, kuabe,serta anyaman), monumen (tugu perpisahan Kaisar Biboki dengan Liurai Sonbay.), ruang hijau (hutan, gunung, dan kebun), kuburan, makanan adat (mak pena, pen pasu, ut, sistunu, se'i bijae dan se'i fafi), pakaian adat, peralatan perang, stakeholder (kelompok usaha pariwisata berbasis adat), tarian adat (tari likurai, tari bonet, tari gong, tarian bersifat senang dan tarian perang), tempat peribadatan (tetu usi neno serta lopo hao).
Potensi warisan budaya intangible yang terdapat di Tamkesi berupa bahasa daerah (Bahasa Dawan Kromo), belonging (rasa kebersamaan dengan meup), cara hidup (bertani, meramu, berburu, kepada raja, taat pada titah raja dan mengikuti norma adat yang berlaku), folklor (bukit Oepuah serta Tapenpah, upacara Tetu Usi Neno, Soanmisokan, dan Faotbeanmetan), norma dan tata nilai (norma dan nilai dari leluhur untuk diri Kaisar Tamkesi, pelanggaran hukum adat, larangan menjatuhkan barang dan berbicara kasar di sekitar kerajaan), hospitality (penduduk desa sangat sopan, baik dan ramah, rumah penduduk cukup bersih dan nyaman, serta penduduk menjamu dan melayani wisatawan dengan baik), spirit, dan suasana (asri, tenang, aman, nyaman).

\section{PENUTUP}

Berikut simpulan yang diuraikan berdasarkan pembahasan hasil penelitian di atas: Desa Wisata Tamkesi mempunyai potensi tangible heritage dan intangibile heritage yang menjadi daya tarik utama bagi wisatawan. Desa ini memiliki potensi heritage dan atraksi wisata yang cukup menakjubkan, namun masih belum dikembangkan secara baik dan memiliki aksesibilitas serta amenitas yang masih sangat minim. Stakeholders yang bertugas untuk mengurus dan mengembangkan kegiatan pariwisata di Desa Wisata Tamkesi adalah kelompok pariwisata adat desa tersebut.

Saran yang diberikan berdasarkan kesimpulan adalah sebagai berikut: Kekayaan potensi warisan budaya tangible dan warisan budaya intangible yang dimiliki masyarakat Kabupaten Biboki perlu diberdayakan untuk menunjang pembangunan pariwisata berkelanjutan yang lebih baik. Stakeholders yang bekerjasama dan berkontribusi dalam pengembangan dan pembangunan pariwisata di Desa Tamkesi pun perlu ditingkatkan hingga dapat mengembangkan kegiatan pariwisata di Desa Tamkesi dengan lebih baik.

\section{DAFTAR PUSTAKA}

Cooper, Chris., Fletcher, John., Gilbert, David and Wanhill, Stephen. 1993. Tourism Principles \& Practice. UK: PITMAN.

Fandeli, Chafid. 2002. Perencanaan Kepariwisataan Alam. Yogyakarta: Fakultas Kehutanan Universitas Gajah Mada.

Hall, Michael dan MacArthur. 1996. Heritage Management in Australia and New Zealand: The Human Dimension. 
Vol. 4 No 2, 2016

Australia: Oxford University Press Australia and New Zealand.

Sukardi, Nyoman. 1998. Pengantar Pariwisata. Bali: Sekolah Tinggi Pariwisata Nusa Dua.

Zalukhu, Sukawati, dan Meyers Koen. 2009. Panduan Dasar Pelaksanaan Ekowisata. Jakarta: Unesco Office. 